\section{ФОРМИРОВАНИЕ ПЕРЕВОДЧЕСКОЙ КОМПЕТЕНЦИИ У СТУДЕНТОВ САМАРСКОГО ГОСУДАРСТВЕННОГО ТЕХНИЧЕСКОГО УНИВЕРСИТЕТА НА ОСНОВЕ УЧЕБНОГО ПОСОБИЯ «ОСНОВЫ ТЕХНИЧЕСКОГО ПЕРЕВОДА: ТЕОРИЯ И ПРАКТИКА"}

\author{
() 2020 И.А. Жаринова \\ Жаринова Ирина Александровна, преподаватель кафедры иностранных языков. \\ E-mail:saverskaya63@mail.ru
}

$$
\text { Самара, Россия }
$$

Статья поступила в редакцию 27.12.2019

\begin{abstract}
Анализ необходимых навыков и знаний для каждой области исследований имеет первостепенное значение, особенно для междисциплинарных областей, таких как перевод. Ученые называют эти навыки и знания компетентностью. Проводится тщательный анализ определения переводческой компетентности, а также категоризация ее компонентов с момента их зарождения, предпринимается попытка сделать обзор различных представлений об этом термине и многочисленных моделях, представленных учеными-переводчиками. Далее анализируются проблемы формирования переводческой компетенции у студентов, обучающихся по специальности «Переводчик в сфере профессиональной компетенции» в Институте дополнительного образования Самарского государственного технического университета, и пути их решения при помощи учебного пособия «Основы технического перевода: теория и практика». Приводятся примеры различных упражнений, помогающих в достижении данной цели.

Ключевые слова: переводческая компетенция, студенты технического ВУЗа, перевод технических текстов.
\end{abstract}

DOI: $10.37313 / 2413-9645-2020-22-71-24-28$

Введение. Владение иностранным языком не только обусловлено образовательными стандартами, но и является неотъемлемой частью культурного развития современного специалиста.

Язык - это средство коммуникации. Наряду с глубокими знаниями основной специальности овладение иностранным языком для современного специалиста является необходимостью, так как даёт хорошие возможности для получения высоко оплачиваемой работы и карьерного роста и возможность быть конкурентоспособным на рынке труда [1, с. 42$]$.

Анализ необходимых навыков и знаний для каждой области исследований имеет первостепенное значение, особенно для междисциплинарных областей, таких как перевод. Ученые называют эти навыки и знания компетентностью. Как сложный термин, определение переводческой компетентности, а также категоризация ее компонентов с момента своего зарождения подвергались изменениям. Некоторые исследователи рассматривали переводческую компетенцию как лингвистическую компетенцию или как сверхкомпетентность; в то время как в более поздних исследованиях используется многокомпонентный взгляд для определения нескольких компетенций, включенных в переводческую компетенцию. В связи с этим в данной статье предпринимается попытка сделать обзор различных представлений об этом термине и многочисленных моделях, представленных учеными-переводчиками.

Как известно, «компетенция» в основном используется в нескольких дисциплинах и контекстах, трудно найти определение, которое бы включало в себя все способы его использования. Более того, считается, что этот термин все еще разрабатывается [2, с. 163]. С другой стороны, интерпретация этого термина также зависит от различных обстоятельств, таких как культурные, лингвистические и национальные. Например, в некоторых случаях этот термин используется для описания процессов формирования навыков, но не аксиоматически в профессиональном развитии и высших когнитивных областях. Как полагает Норрис [3, с. 1], определение компетенции усложнилось.

Описывая компетентность как нечеткое понятие, ряд исследователей (Бун и Ван Дер Клинг [4, c. 327]) признают, что компетентность преодоле- 
вает разрыв между требованиями к образованию и профессии. В значительной степени признается, что компетенция - это сочетание способностей, навыков и знаний, проявляющихся в конкретных действиях и ситуациях [5 с. 201]. Кроме того, компетенция, несомненно, многогранна и включает в себя личные компоненты (знания, когнитивные навыки, мотивацию, установки и эмоции), социокультурные компоненты (понимание контекста) и поведение (действия, поведение и инициативы). Пытаясь преодолеть разрыв между психологическими, педагогическими и социологическими аспектами «компетенции» [6, с. 45], Вейнерт определяет компетенцию в своей статье как «...грубо специализированную систему способностей, умений или навыков, необходимых для достижения конкретной цели» [7, c. 45]. Одно из наиболее полных определений, на наш взгляд, представляет Ласнер:

«Компетенция - это сложное понятие, которое возникает в результате интеграции, мобилизации и организации сочетания способностей и навыков (которые могут быть когнитивными, аффективными, психомоторными или социальными) и знаний, эффективно используемых в ситуациях с общими характеристиками» [8, с. 34].

В том же ключе Гонзалез и Вагнер определяют компетентность как «совокупность навыков, знаний, умений и включает в себя способность к обучению» [9, с. 10].

Переводческая компетенция рассматривается и определяется по-разному. На ранних стадиях (в 1970-х годов и ранее) она отражалась в виде двуязычия [10, с. 482]. Однако начиная с 1980-х годов, эта точка зрения резко изменилась в связи с различными социальными, политическими и историческими изменениями, кульминацией которых стало, в частности, начало 1990-х годов, что привело к фундаментальным изменениям в требованиях рынка. С этого времени «переводческая компетентность» рассматривалась как многокомпонентная компетентность, которая включает в себя набор технологических, культурных или лингвистических навыков. Переводческая компетентность требует «межъязыковой компетентности», которая основана на соответствующих инклюзивных знаниях и включает в себя набор знаний и навыков, которыми обладает переводчик. Переводческая компетенция также рассматривается как коммуникативное посредничество в различных сферах деятельности, а именно знания, умения и навыки, направленные на адекватное восприятие, интерпретацию текста и коммуникативный эффект [6, с. 102]. В нашей работе под переводческой компетентностью понимается основополагающая система знаний и навыков, необходимых для умения переводить.

Производственные контакты с иностранными специалистами определяют важность раз- вития навыков перевода у будущих инженеров. Основными видами иноязычной компетенции обучающихся являются чтение и перевод оригинальной специализированной литературы научного характера, ее поиск, осмысление и обработка с целью дальнейшего практического применения [11, с. 75].

Технический перевод - это выражение в письменной или устной форме специальной научно-технической информации, которая уже была выражена на другом языке, средствами другого языка. Чаще всего переводчику приходится иметь дело с новой информацией в разных областях науки и техники. На практике при переводе большинства сложных текстов используются различные способы, но их можно сгруппировать в два вида:

$\checkmark$ полный письменный перевод;

$\checkmark$ сокращенный вид в форме реферата, аннотации и т.д.

Переводчик должен владеть всеми видами обработки первичной информации, но при этом располагать определенной суммой специальных знаний. Овладеть системой лингвистических знаний, включающей в себя знание основных фонетических, лексических, грамматических словообразовательных явлений и закономерностей английского языка, дело весьма трудное. Поэтому важной задачей преподавателя является создание системы освоения лексических трудностей перевода, включающей упражнения и комментарии, которые будут способствовать более глубокому усвоению студентами учебного материала и могут быть использованы как для аудиторной, так и для самостоятельной работы.

Целью данной работы является формирование навыков переводческой компетенции через овладение лексическими особенностями технических текстов.

Актуальность исследования находит свое отражение в доказательстве продуктивности использования упражнений при обучении техническому переводу студентов, обучающихся по специальности «Переводчик в сфере профессиональной компетенции» в Институте дополнительного образования Самарского государственного технического университета.

Анализ теоретических исследований по выбранной проблеме приводит к выявлению определенных закономерностей, позволяющих утверждать, что методически грамотное использование упражнений способствует эффективному формированию переводческих навыков и умений у студентов.

Рассмотрим систему таких упражнений, на примере учебного пособия «Основы технического перевода: теория и практика», предусматривающая операции с единицами языка и формирующая элементарные навыки перевода. 
I. Translate the following sentences, paying special attention to the meaning of the word matter. Данный тип упражнений направлен на увеличение словарного запаса, тем самым помогая избежать тавтологии.

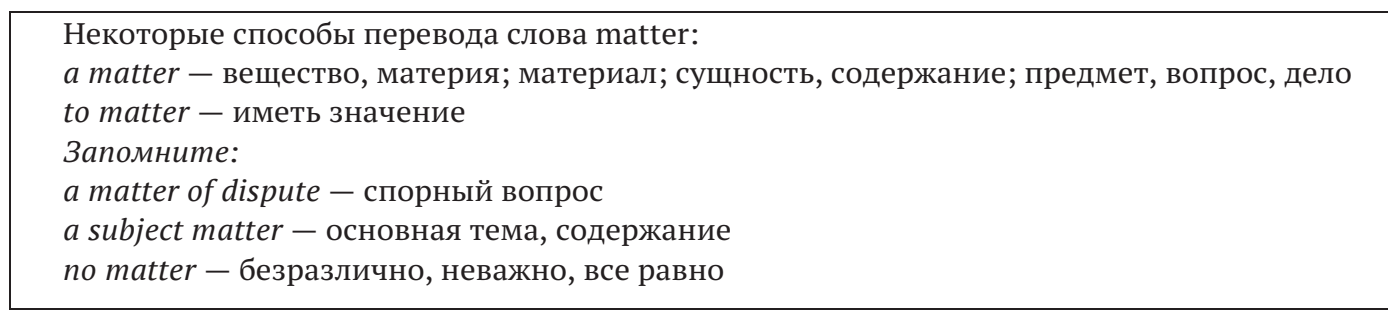

The contribution of white matter changes (WMCs), seen with computed tomography (CT) and magnetic resonance imaging (MRI) of the brain, to dementia had not been fully elucidated. 2. We report first results from the ZEPLIN I dark matter detector, based on measurement of scintillation pulse shapes in a liquid xenon target of $3.2 \mathrm{~kg}$ fiducial mass. 3 . The background and some unique research projects being promoted on shock waves in condensed matter are described in two areas in shock-material processing and shock physics in condensed matter.

II. Translate the following sentences. Mind the information in the box.

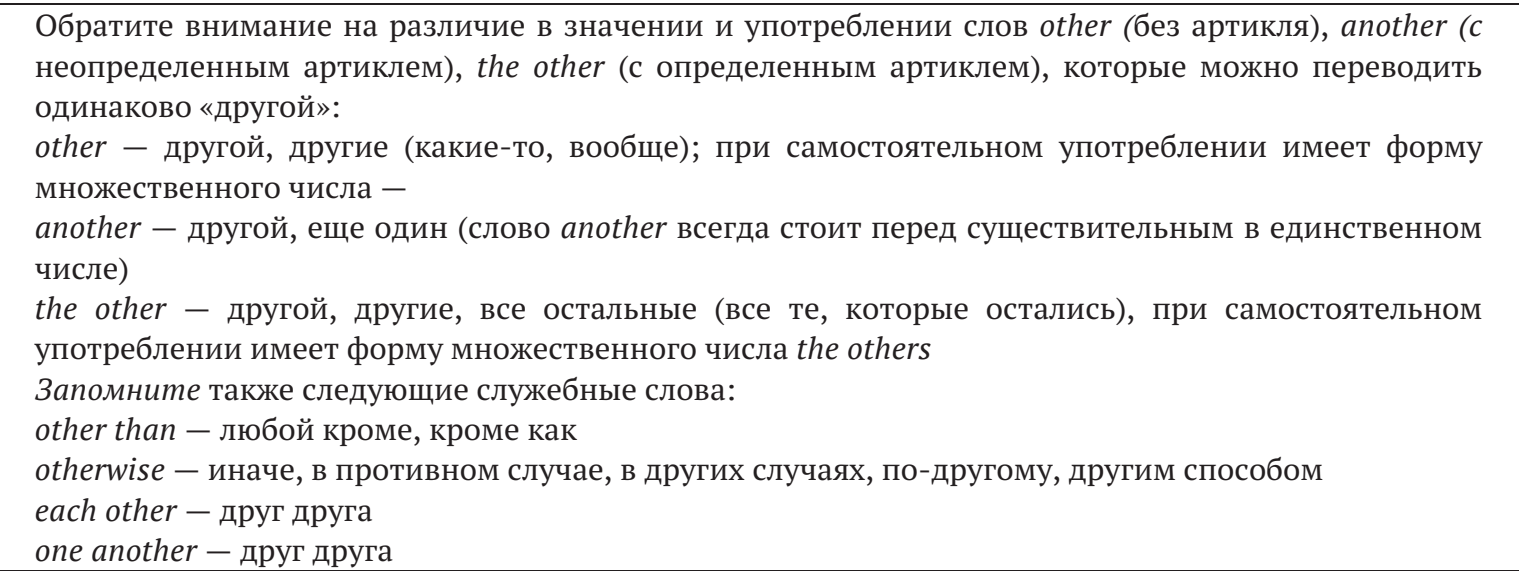

1. The study has shown a significant reduction in the rate of lost life years for crash-involved other road users as driver age increases. 2 . The objective is to investigate the current status of medical support in military operations other than war (MOOTW) in domestic and overseas. 3 . The present study was the first to use the functional magnetic resonance imaging (fMRI) methodology to investigate the neural correlates of race categorization of own- and other-race faces. 4. We discuss how this tendency fits in the broader literature on self-other differences in evaluation and how it contributes to above-average effect.

II. Find appropriate term to the definition:

a)A deep hole in the ground from which water, oil or gas can be obtained

b) The ability to think carefully about something you are doing and nothing else
1) concentration

2) well

III. Fill in the table. Данное упражнение вырабатывает умение образовывать различные части речи, способствуя расширению словарного запаса студента.

\begin{tabular}{|l|l|l|}
\hline VERB & NOUN (ACTION) & NOUN (AGENT) \\
\hline to develop & development & developer \\
\hline to consume & & consumer \\
\hline & generation & \\
\hline & compression & \\
\hline to design & & \\
\hline & migration & \\
\hline to connect & & \\
\hline & & transmitter \\
\hline
\end{tabular}


VI. Give the full form of the given abbreviations and translate them into Russian

\begin{tabular}{|l|l|}
\hline a c & \\
\hline $\mathrm{AF}$ & \\
$\mathrm{d} c$ & \\
\hline $\mathrm{CFG}$ & \\
\hline emf & \\
\hline
\end{tabular}

Итак, использование упражнений играет важную роль, давая учащимся отработать навыки перевода, применить новую лексику и грамматику, правильно использовать устойчивые выражения и фразы. Конечно же, упражнения не могут заменить другие методики. Просто каждой из них должно быть найдено оптимальное место в учебном процессе.

Использование упражнений, приведенных в анализируемом учебном пособии, спо-

собствует развитию знаний лексической стороны языка, умению правильно оценивать и выбирать языковые средства в процессе перевода, владению навыком изложения своих знаний в письменном и устном виде. Практическая значимость связана с социальным запросом любого современного общества, так как оно нуждается в знании иностранных языков, в их успешном функционировании и применении.

1. Кюрегян, А. Л., Рыбальчик О. А. Конкурс переводчиков научно-технической литературы как инструмент формирования переводческой компетенции у студентов электротехнического факультета СамГТУ // Вестник Самарского государственного технического университета. Психолого-педагогические науки. - Самара, Самарский государственный технический университет, 2017. - C. 41 - 46.

2. Hurtado, Albir A. (2007). Competence-based curriculum design for training translators. The Interpreter and Translator Trainer, 1(2), 163 - 195.

3. Norris, N. (1991). The trouble with competence. Cambridge Journal of Education, 21(3), 1-11.

4. Boon, J. \& van der Klink, M. (2002). Competencies: The triumph of a fuzzy concept. proceedings of academy of human resource development annual conference,Vol.1, (pp. 327 - 334). Honolulu.

5. Hansen, G. (1997). Success in Translation. Perspectives: Studies in Translatology, 5(2), pp. $201-210$.

6. Кюрегян, А.Л., Рыбальчик, О.А. Technical English for Electrical Engineers: учебное пособие. - Самара, Самарский государственный технический университет, 2014. - 118 с.

7. Weinert, F. E. (2001). Concept of competence: A conceptual clarification. In S. Rychen, \& H. Salganik (Eds.), Defining and selecting key competences (pp. 45 - 65). Seattle: Hogrefe ans Huber Publishers.

8. Lasnier, F. (2000). Reussir la formation par competences. Montreal: Guerin.

9. Gonzalez, J., \& Wagenaar, R. (2003). Tuning educational structures in Europe. Inform final. Fase 1, Universidades de Deusto i Groningen.

10. Pym, A. (2003). Redefining Translation Competence in an Electronic Age. Defense of a Minimalist Approach, Meta, $48(4), 48-49$.

11. Гуцол, Ю. В., Жаринова, И. А. KEYPAL - технология в процессе формирования иноязычного общения студентов // Известия Самарского научного центра РАН. Социальные, гуманитарные, медико-биологические науки. - 2018, том 20. - №2. - С. 43 - 49.

12. Доброва, В. В., Елизарова Е. А., Сысуева, И. Г., Гришина, И. А. Основы технического перевода: теория и практика. - Самар. гос.тех. ун-т, 2013. - 174 с.

\title{
FORMATION OF TRANSLATION COMPETENCE AMONG STUDENTS OF SAMARA STATE TECHNICAL UNIVERSITY ON THE BASIS OF THE TEXTBOOK «BASICS OF TECHNICAL TRANSLATION: THEORY AND PRACTICE»
}

\author{
(c) 2020 I.A. Zharinova \\ Zharinova Irina Aleksandrovna, teacher, Department of Foreign Languages. \\ E-mail:saverskaya63@mail.ru \\ Samara State Technical University. \\ Samara, Russia
}

The analysis of the skills and knowledge required for each area of research is of paramount importance, especially for interdisciplinary areas such as translation. Scientists refer to these skills and knowledge as competence. A thorough analysis of the definition of translation competence, as well as the categorization of its components since its origin, is carried out, and an attempt is made to give an overview of the different visions of the term and the numerous models presented by the translators. 
Further, the problems of forming translation competence of students studying in the Institute of Further Education of Samara State Technical University and the ways of their solution with the help of the textbook «Fundamentals of Technical Translation: Theory and Practice» are analyzed. Examples are given of various exercises that help to achieve this goal.

Keywords: translation competence, students of technical university, translation of technical texts.

DOI: $10.37313 / 2413-9645-2020-22-71-24-28$

1. Kyuregyan, A. L., Rybal'chik O.A. Konkurs perevodchikov nauchno-tekhnicheskoy literatury kak instrument formirovaniya perevodcheskoy kompetentsii u studentov elektrotekhnicheskogo fakul'teta SamGTU (Competition of translators of scientific and technical literature as a tool for the formation of translation competence among students of the Faculty of Electrical Engineering of Samara State Technical University) // Vestnik Samarskogo gosudarst-vennogo tekhnicheskogo universiteta. Psikhologo-pedagogicheskiye nauki. - Samara, Samarskiy gosudarstvennyy tekhnicheskiy universitet, 2017. - S. 41 - 46.

2. Hurtado, Albir A. (2007). Competence-based curriculum design for training translators. The Interpreter and Translator Trainer, 1(2), 163 - 195.

3. Norris, N. (1991). The trouble with competence. Cambridge Journal of Education, 21(3), 1-11.

4. Boon, J. \& van der Klink, M. (2002). Competencies: The triumph of a fuzzy concept. proceedings of academy of human resource development annual conference,Vol.1, (pp. 327 - 334). Honolulu.

5. Hansen, G. (1997). Success in Translation. Perspectives: Studies in Translatology, 5(2), rp. $201-210$.

6. Kyuregyan, A.L., Rybal'chik, O.A. Technical English for Electrical Engineers: uchebnoye posobiye. - Samara, Samarskiy gosu-darstvennyy tekhnicheskiy universitet, 2014. - 118 c.

7. Weinert, F.E. (2001). Concept of competence: A conceptual clarification. In S. Rychen, \& H. Salganik (Eds.), Defining and se-lecting key competences (pp. 45 - 65). Seattle: Hogrefe ans Huber Publishers.

8. Lasnier, F. (2000). Reussir la formation par competences. Montreal: Guerin.

9. Gonzalez, J., \& Wagenaar, R. (2003). Tuning educational structures in Europe. Inform final. Fase 1, Universidades de Deusto i Groningen.

10. Pym, A. (2003). Redefining Translation Competence in an Electronic Age. Defense of a Minimalist Approach, Meta, $48(4), 48-49$.

11. Gutsol, YU. V., Zharinova, I. A. KEYPAL - tekhnologiya v protsesse formirovaniya inoyazychnogo obshcheniya studentov (KEYPAL - technology in the process of forming students' foreign language communication) // Izvestiya Samarskogo nauchnogo tsentra RAN. Sotsial'nyye, gumanitarnyye, mediko-biologicheskiye nauki. - 2018, tom 20. - №2. - S. $43-49$.

12. Dobrova, V. V., Yelizarova Ye. A., Sysuyeva, I. G., Grishina, I. A. Osnovy tekhnicheskogo perevoda: teoriya i praktika (Fundamentals of technical translation: theory and practice). - Samar. gos.tekh. un-t, 2013. - $174 \mathrm{~s}$. 